\title{
PENULISAN HADIS PADA MASA RASULULLAH SAW.
}

\author{
Latifah Anwar \\ latifah.anwar18@gmail.com. \\ Ilmu Hadis, Fakultas Ushuluddin dan Filsafat, Universitas Islam Negeri Sunan Ampel \\ Surabaya, Indonesia
}

\begin{abstract}
In Islam, Hadith becomes the second guidelines after Al-Quran, therefore, Moslem had done a lot of efforts to keep its authenticity. At the beginning of Muhammad prophecy, there was no any Hadith coding as like Al-Quran. The existence of Hadith narration in Prophet Muhammad era was still debated because of the two contradictory Hadith riwayah. One of them indicated the prohibition for Hadith narration, and other directed its approval which led Hadith narration. Compared with ummi group, in Prophet Muhammad era, only few of Prophet Muhammad companions were able to write. In accepting the Hadith narration, the companions relied on the memorization than writing. The majority of Hadith Preachers assumed that, Hadith had been written by the companions when Prophet Muhammad was still alive. Whereas, the orientalist and some of modern Moslem experts mentioned that Hadith had not been written in Prophet Muhammad era. Some of the companions had their own Hadith writing, although there were any contradictory Hadith between prohibition and approval in Hadith writing. Only few companions who wrote Hadith, such as 'Abdullah Ibn 'Amr Ibn 'Al-Ash, allowed by Prophet Muhammad to write Hadith. Prophet Muhammad never instructed certain companion to write and compile Hadith as like Al-Quran which was officially written by Prophet Muhammad's individual secretary, Zayd Ibn Tsabit. Whereas, the officially Hadith coding was started at Umar ibn 'Abd al 'Aziz era (99H $101 \mathrm{H})$.
\end{abstract}

Keywords: Writing of the Hadith; Rasulullah.

\begin{abstract}
Abstrak
Hadis merupakan pedoman kedua dalam agama Islam setelah al-Qur'an sehingga banyak sekali upaya yang dilakukan umat Islam sejak masa sahabat untuk menjaga keotentikannya. Pada awal kenabian, belum ada kodifikasi hadis seperti halnya al-Qur'an. Adanya catatan-catatan hadis pada masa Rasulullah Saw. juga masih diperdebatkan, karena terdapat dua riwayat hadis yang tampak bertentangan. Salah satu riwayat dari Rasulullah Saw. mengindikasikan adanya larangan penulisan hadis. Namun, ada riwayat lain dari Rasulullah Saw. yang membolehkan penulisan hadis, dan terjadi kegiatan penulisan hadis. Pada masa Rasulullah, sahabat yang mampu menulis hanya sedikit, sedangkan golongan ummi lebih dominan dibandingkan sahabat yang bisa menulis. Dalam menerima periwayatan hadis dari Rasulullah Saw. para sahabat lebih banyak mengandalkan hafalannya daripada tulisan. Mayoritas ulama hadis berpendapat bahwa, hadis telah dicatat oleh para sahabat ketika Nabi Muhammad masih hidup. Sedangkan para orientalis dan sebagian pemikir muslim modern berpendapat
\end{abstract}


bahwa, hadis belum dicatat pada masa Rasulullah Saw. Sebagian sahabat ada yang memiliki tulisan hadis secara pribadi meskipun terdapat hadis-hadis yang saling bertentangan antara larangan dan izin dalam penulisan hadis. Hanya sedikit dari golongan sahabat yang menulis hadis seperti 'Abdullah ibn 'Amr ibn al-'Ash yang diberikan ijin oleh Rasulullah SAW. untuk menulis hadis. Rasulullah tidak pernah memerintah sahabat tertentu untuk menulis dan membukukan hadis sebagaimana alQur'an yang ditulis secara resmi oleh sekretaris pribadi Rasulullah Saw. Zayd ibn Tsabit. Sedangkan kodifikasi hadis secara resmi baru terjadi pada masa Khalifah 'Umar ibn 'Abd al-'Aziz (99 H-101 H).

Kata Kunci: Penulisan Hadis; Rasulullah.

\section{A. Pendahuluan}

Periode Rasulullah Saw. merupakan periode pertama sejarah pertumbuhan hadis. Periode ini terhitung cukup singkat bila dibandingkan dengan masa-masa berikutnya. Masa ini berlangsung selama 23 tahun, mulai tahun 13 sebelum Hijriyah, bertepatan dengan tahun 610 Masehi sampai dengan tahun 11 Hijriyah, betepatan dengan tahun 632 Masehi. Masa ini merupakan kurun waktu turun wahyu ('ashr al-wahyi) dan sekaligus sebagai masa pertumbuan hadis. Keadaan tersebut sangat menuntut keseriusan dan kehati-hatian para sahabat sebagai pewaris pertama ajaran Islam dalam menerima kedua sumber ajaran tersebut. Pada tangan mereka, kedua-duanya harus terpelihara dan disampaikan kepada pewaris berikutnya secara berkesinambungan. ${ }^{1}$

Hadis mempunyai peran penting dan memiliki korelasi dengan al-Qur'an, karena sebagian hadis ada yang menjelaskan tentang asbab al-nuzul yang menguak pesanpesan dalam ayat al-Qur'an. Informasi asbab al-nuzul ini terdapat dalam catatan hadis. Jadi, untuk memahami al-Qur'an dengan baik dibutuhkan bantuan informasi dari hadis. Tanpa informasi hadis, misi al-Qur'an tidak dapat diketahui dengan jelas. Karena itu, bagi orang Islam, keduanya menjadi sumber ajaran Islam. Bahkan dikatakan, keduanya wahyu Ilahi. Al-Qur'an itu wahyu yang matluw, dibacakan oleh malaikat Jibril kepada Nabi Muhammad Saw., sedangkan hadis disebut wahyu ghair matluw. ${ }^{2}$

Secara umum, digambarkan adanya Rasulullah yang ummi sebagai penyampai dan pen-syarah al-Qur'an. Rasulullah sebagai pelaku sejarah yang dikelilingi oleh para

\footnotetext{
${ }^{1}$ Sohari Sahrani, Ulumul Hadits (Bogor: Ghalia Indonesia, 2010), 48

${ }^{2}$ Muh. Zuhri, Telaah Matan Hadis Sebuah Tawaran Metodologis (Yoyakarta: LESFI, 2003), 1-2
} 
sahabat yang menjadi pengikut dan sasaran risalah-nya. Semua hal yang berhubungan dengan Rasulullah, baik yang berkaitan dengan misi kerasulannya atau tidak, menjadikan kekayaan memorial para sahabat dalam kapasitas mereka sebagai teman, murid, prajurit dan seterusnya. ${ }^{3}$

Pada masa Nabi, sedikit sekali sahabat yang dapat menulis, sehingga yang menjadi andalan mereka dalam menerima hadis adalah ingatan mereka. Menurut 'Abd al-Nashr, Allah telah memberikan keistimewaaan kepada para sahabat kekuatan daya ingat dan kemampuan menghafal. Mereka dapat meriwayatkan al-Qur'an, hadis dan syair dengan baik seakan-akan mereka membaca dari sebuah buku. ${ }^{4}$

Para sahabat sangat antusias untuk menghadiri majlis Rasulullah SAW., menimba ilmu darinya dan meneladani beliau. Jika berhalangan hadir karena sibuk dengan mata pencaharian, maka mereka saling bergantian dan yang hadir menyampaikan kepada yang tidak hadir dalam majlis tersebut. ${ }^{5}$

Pada masa Nabi, hadis belum dikodifikasi secara resmi sebagaimana yang terjadi pada beberapa tahun berikutnya, yakni pada masa Khalifah 'Umar ibn 'Abd al'Aziz (99 H-101 H). Rasulullah tidak pernah memerintah sahabat tertentu untuk menulis hadis dan membukukannya sebagaimana al-Qur'an yang ditulis secara resmi oleh Zayd ibn Tsabit, sekretaris pribadi Rasulullah Saw. ${ }^{6}$

Untuk memelihara kemurnian dan mencapai kemaslahatan al-Qur'an dan hadis sebagai sumber ajaran Islam, Rasulullah SAW. mengambil kebijaksanaan yang berbeda. Terhadap al-Qur'an, beliau secara resmi memberi instruksi kepada sahabat tertentu supaya menulis selain menghafalnya. Sedangkan terhadap hadis, perintah resmi hanya untuk menghafal dan menyampaikannya kepada orang lain. Penulisan resmi seperti halnya al-Qur'an tidak diperkenakan Rasulullah Saw. ${ }^{7}$

\footnotetext{
${ }^{3}$ Daniel Djuned, Ilmu Hadis (t.t.: Erlangga, 2010), 15

${ }^{4}$ Idri, Hadis dan Orientalis: Perspektif Ulama Hadis dan Para Orientalis tentang Hadis Nabi (Jakarta: Kencana, 2017), 38

${ }^{5}$ Manna' al-Qaththan, Pengantar Studi Ilmu Hadits, terj. Mifdhol Abdurrahman (Jakarta: al-Kautsar, 205), 44

${ }^{6}$ Idri, Hadis dan Orientalis..., 38

${ }^{7}$ Sahrani, Ulumul Hadits..., 53-54
} 
Rasulullah melarang menulis hadis karena khawatir hadis tercampur dengan alQur'an yang saat itu masih dalam proses penurunan wahyu (al-tanzil). ${ }^{8}$ Nabi melarang menulis hadis karena khawatir tercampur dengan al-Qur'an dan pada kesempatan lain Nabi membolehkannya. ${ }^{9}$

Wahyu yang diturunkan Allah Swt. kepada Rasulullah Saw. dijelaskan melalui perkataan (aqwal), perbuatan ( $\left.a f^{\prime} a l\right)$, dan ketetapannya (taqrir) di hadapan para sahabat. Apa yang di dengar, dilihat, dan disaksikan oleh mereka merupakan pedoman baik amaliah dan 'ubudiyah mereka sehari-hari. Dalam hal ini, Rasulullah Saw. merupakan contoh satu-satunya bagi para sahabat, karena ia memiliki sifat kesempurnaan dan keutamaan selaku utusan Allah yang berbeda dengan manusia lainnya. ${ }^{10}$

Hadis yang sampai kepada generasi mukharrij (penghimpun hadis) melalui jalur periwayatan yang panjang dan dalam tempo yang lama, sehingga memungkinkan masuknya berbagai unsur dari luar dalam proses periwayatan. Hal tersebut memerlukan perhatian yang khusus sehingga dapat terjaga dari upaya percampuran hadis dengan unsur lain. ${ }^{11}$

\section{B. Perkembangan Tulis-menulis pada Masa Rasulullah Saw.}

Sebelum datangnya Islam, bangsa Arab tidak dikenal dengan kemampuan membaca dan menulis, sehingga mereka lebih dikenal sebagai bangsa yang ummi (tidak bisa membaca dan menulis). Namun demikian, ini tidak berarti bahwa di antara mereka tidak ada seorangpun yang bisa menulis dan membaca. Keadaaan ini hanyalah sebagai ciri kebanyakan dari mereka. Sejarah telah mencatat bahwa sejumlah orang di antara mereka ada yang mampu membaca dan menulis. Adiy ibn Zaid al-Abbadiy (w. 35 SH) misalnya, sudah belajar menulis hingga menguasainya, dan merupakan orang pertama yang menulis dengan bahasa Arab dalam surat yang ditujukan kepada Kisra. Sebagian orang Yahudi juga mengajarkan anak-anaknya di Madinah menulis Arab. Kota Makkah

\footnotetext{
${ }^{8}$ Idri, Hadis dan Orientalis..., 38

${ }^{9}$ Ibid., 39

${ }^{10}$ Sahrani, Ulumul Hadits..., 48

${ }^{11}$ Salamah Noorhidayati, Kritik Teks Hadis (Yogyakarta: Dialektika, 2017), 1
} 
dengan pusat perdangannya sebelum kenabian menjadi saksi adanya para penulis dan orang-orang yang mampu membaca. ${ }^{12}$

Para sahabat Rasul adalah orang Arab tulen yang mayoritas tidak bisa baca-tulis, namun demikian mereka mempunyai kemampuan hafalan yang luar biasa. Semenjak zaman Jahiliyyah mereka biasa menghafal nasab atau garis keturunan sampai nenek moyang mereka, riwayat-riwayat tentang kejadian yang mereka alami. Bahkan, mereka hafal syair-syair dan khitabah-khitabah yang pernah diucapkan. Dengan kekuatan hafalan bangsa Arab yang demikian itu, seolah-olah Allah telah mempersiapkan mereka untuk mendukung datangnya kenabian Muhammad Saw. ${ }^{13}$

Ketika Islam datang, di kalangan suku Quraisy terdapat 17 orang yang dapat menulis, tetapi jumlah ini tidak dapat dijadikan patokan, apalagi mengingat letak Makkah yang sangat strategis untuk perdagangan, disamping sebagai pusat kegiatan agama. Di sisi lain, nama-nama penulis yang disebutkan al-Baladzuri tidak mencakup orang-orang Makkah yang dikenal dapat menulis seperti Abu Bakar al-Shiddiq, 'Abdullah ibn 'Amr ibn al-'Ash, dan Sufyan ibn Harb. ${ }^{14}$

Pada masa-masa awal, anak-anak di Madinah juga belajar menulis. Munurut alWaqidi, jumlah mereka yang dapat menulis tidak lebih dari sebelas orang. Seperti halnya di Makkah, jumlah pendudk Madinah yang mengetahui tulis-menulis relatif sedikit. $^{15}$

Banyak akhbar yang menunjukkan bahwa para penulis lebih banyak di Makkah daripada di Madinah. Hal ini dibuktikan bahwa Rasulullah mengizinkan tawanan dari Makkah dalam perang Badar yang mampu menulis untuk mengajarkan menulis dan membaca kepada 10 anak Madinah sebagai tebusan diri mereka. ${ }^{16}$

\footnotetext{
${ }^{12}$ al-Qaththan, Pengantar Studi..., 45

${ }^{13}$ Lukman Zain, "Sejarah Hadis pada Masa Permulaan dan Penghimpunannya", Diya al-Afkar, Vol. 2, No. 1 ( Juni 2014), 1

${ }^{14}$ M.M. Azami, Hadis Nabawi dan Sejarah Kodifikasinya, terj. Ali Mustafa Yaqub (Jakarta: Pustaka Firdaus, 1994), 133

${ }^{15}$ Azami, Hadis Nabawi..., 133

${ }^{16}$ al-Qaththan, Pengantar Studi..., 46
} 
Rasulullah memerintahkan anak-anak untuk belajar di masjid kampung mereka. Pada tahun pertama Hijriyah Rasulullah Saw. memerintahkan untuk menghitung (menyensus) jumlah kaum muslimin di Madinah, baik dewasa maupun anak-anak, lakilaki ataupun perempuan. ${ }^{17}$

Pada masa Nabi SAW. tulis-menulis sudah tersebar luas. Al-Qur'an sendiri menganjurkan untuk belajar dan membaca. Rasulullah sendiri mengangkat para penulis wahyu yang jumlahnya mencapai 40 orang, dan nama-nama mereka disebut dalam kitab al-Taratib al-Idariyyah. Bahkan, dalam kitab Futuh al-Buldan disebutkan adanya sejumlah penulis wanita, di antara mereka yaitu; Ummul Mu'minin Hafshah, Ummu Kultsum bintu 'Uqbah, al-Syifa' bintu 'Abdullah al-Qurasyiyyah, 'Aisyah bintu Sa 'ad, Karimah bintu al-Miqdad. ${ }^{18}$

Orang pertama yang menjadi penulis wahyu bagi Nabi di periode Makkah ialah 'Abdullah ibn Sarh. Para khalifah yang empat juga menjadi penulis wahyu, begitu pula al-Zubair ibn 'Awwam, Khalid dan Aban dua putera Sa'id ibn al-'Ash ibn Umayyah, Hanzhalah ibn al-Rabi' al-Asadi, Mu'ayqib ibn Abi Fathimah, 'Abdullah ibn al-Arqam al-Zuhri, Syurahbil ibn Hasanah, dan 'Abdullah ibn Rawahah. Setelah hijrah ke Madinah, maka yang mula-mula menjadi penulis wahyu ialah Ubay ibn Ka'ab. Kemudian diikuti oleh Zayd ibn Tsabit dan sejumlah sahabat lainnya. ${ }^{19}$

Sekretaris Nabi ada yang bersifat sementara, ada juga yang menjadi sekretaris tetap. Hanya saja kebanyakan mereka menulis masalah-masalah khusus, sehingga ada yang menulis al-Qur'an saja seperti 'Ali ibn Abi Thalib, 'Utsman ibn 'Affan, Zaid ibn Tsabit, dan Ubay ibn $\mathrm{Ka}^{\circ} \mathrm{ab} .^{20}$

Bahan-bahan yang dijadikan untuk mencatat wahyu-wahyu yang turun ialah benda-benda dapat ditulis dan mudah didapatkan waktu itu seperti al-riqa' (batu, pelepah kurma, tulanng, dan sebagainya). ${ }^{21}$ Dalam pencatatan wahyu tersebut, para

\footnotetext{
${ }^{17}$ Subhi al-Shalih, Membahas Ilmu-ilmu Hadis, terj. Tim Pustaka Firdaus (Jakarta: Pustaka Firdaus, 2009), 34

18 al-Qaththan, Pengantar Studi..., 46

${ }^{19}$ Nashruddin Baidan, Wawasan Baru Ilmu Tafsir (Yoyakarta: Pustaka Pelajar, 2011), 27

${ }^{20}$ Azami, Hadis Nabawi..., 88

${ }^{21}$ Baidan, Wawasan Baru..., 27
} 
penulis wahyu mengikuti pedoman yang digariskan, antara lain mereka tidak dibenarkan sedikitpun menuliskan apa yang disampaikan Nabi selain al-Qur'an. ${ }^{22}$

Selain itu, Ada juga yang secara khusus mencatat harta-harta sedekah, seperti Zubair ibn al-'Awwam dan Jahm ibn Shalit. 'Abdullah ibn al-Arqam al-'Ala' ibn 'Uqbah mencatat masalah-masalah hutang dan perjanjian-perjanjian lain. Sedangkan Khudaifah ibn al-Yaman mencatat taksiran hasil kurma. Mu'aiqib ibn Abu Fathimah alDusi mencatat maghanim Nabi Saw., dan Hanzhalah yang menjadi sekretaris cadangan selalu membawa stempel Nabi Saw.

Sedangkan sahabat yang diperintahkan oleh Nabi untuk mempelajari bahasa asing yaitu Zaid ibn Tsabit. Ia mempelajari bahasa Suryani yang kemudian menjadi penerjemah Nabi dalam hal-hal yang bertalian dengan bahasa tersebut. ${ }^{23}$

Tulisan-tulisan saat itu tidak hanya membahas masalah-masalah agama saja, tetapi juga mencakup materi-materi lain yang secara umum dapat dibagi menjadi dua, yaitu tulisan-tulisan yang membahas materi non agama dan tulisan-tulisan yang membahas materi agama. ${ }^{24}$

Para penulis semakin banyak di Madinah setelah perang Badar. Nabi menyuruh 'Abdullah ibn Sa'id ibn 'Ash agar mengajarkan menulis di Madinah. Ibnu Hajar menyebutkan bahwa nama asli 'Abdullah ibn Sa'id ibn 'Ash adalah al-Hakam, lalu Rasulullah memberinya nama dengan 'Abdullah, dan menyuruhnya agar mengajar menulis di Madinah. ${ }^{25}$

Adanya dugaan ketidakmampuan baca-tulis pada bangsa Arab sebagai faktor keterlambatan kodifikasi hadis dapat terbantahkan. Demikian halnya pendapat Muhammad Musthafa al-Azami dengan mengatakan bahwa penulis-penulis pada masa

\footnotetext{
${ }^{22}$ Ibid., 28

${ }^{23}$ Azami, Hadis Nabawi..., 88

${ }^{24}$ Ibid., 89

${ }^{25}$ al-Qaththan, Pengantar Studi..., 47
} 
Nabi telah berkembang pesat, dimana al-Qur'an dapat dirangkum dengan sekumpulan naskah-naskah yang ada pada sahabat-sahabat yang menulis wahyu al-Qur'an. ${ }^{26}$

\section{Periwayatan Hadis pada Masa Rasulullah Saw.}

Nabi Muhammad SAW. menyampaikan risalahnya selama 23 tahun. Dalam masa yang relatif singkat ini agama Islam telah tersebar ke sebagian besar jazirah Arab. Oleh para ulama, masa ini disebut sebagai masa atau periode pengajaran Islam dan peletakan dasar yang kuat bagi kebudayaan dan peradaban Islam. ${ }^{27}$

Ada suatu keistimewaan pada masa ini yang membedakannya dengan masa lainnya, yaitu umat Islam dapat secara langsung memperoleh hadis dari Rasulullah SAW. sebagai sumber hadis. Pada masa ini tidak ada jarak atau hijab yang dapat menghambat atau mempersulit pertemuan mereka.

Tempat-tempat pertemuan kedua belah pihak sangatlah terbuka dalam berbagai kesempatan, misalnya masjid, rumah Rasulullah, pasar, atau ketika beliau dalam perjalanan (safar), dan ketika beliau muqim (berada di rumah). Melalui tempat-tempat tersebut, Rasulullah SAW. menyampaikan hadis. ${ }^{28}$

Metode yang dipakai oleh Rasulullah saw. dalam mengajarkan ajarannya kepada sahabat, yaitu:

1. Mengajarkan secara bertahap (tadarruj). Cara ini ditempuh oleh Nabi seiring dengan cara al-Qur'an dalam memperbaiki akidah bangsa Arab yang rusak, yakni tidak langsung sekaligus. Hal ini sesuai dengan rahasia diturunkannya al-Qur'an secara berangsur-angsur.

2. Dalam mengajarkan ajarannya, Nabi tidak terikat oleh waktu dan tempat. Sehingga bisa dikatakan, di mana ada kesempatan disitulah Nabi menyampaikan ajarannya.

3. Mendidik dan mengajarkannya dengan akhlak yang mulia, dan tidak mempersulit dalam penyampaian. Beliau benar-benar memperhatikan kondisi dan situasi serta kadar kemampuan umat dan sahabatnya.

\footnotetext{
${ }^{26}$ Muhammad Abduh, "Melacak Akar Kesejarahan Hadis Nabi Pra-Kodifikasi”, Tahdis, Vol. 6, No. 1 (2015), 66

${ }^{27}$ Noorhidayati, Kritik Teks..., 20

${ }^{28}$ Mudasir, Ilmu Hadis (Bandung: Pustaka Setia, 1999), 88
} 
4. Untuk tidak menimbulkan kejenuhan, Nabi menempuh berbagai metode yang variatif dan berubah-ubah sesuai dengan kondisi dan kebutuhan umat.

5. Nabi tidak mengabaikan pengajaran terhadap kaum perempuan. ${ }^{29}$

Pada masa Rasulullah, hanya sedikit dari sahabat Nabi yang mampu menulis dengan baik. Sedangkan golongan ummi> lebih dominan dibandingkan sahabat yang bisa menulis. Maka cara yang digunakan oleh sahabat dalam menerima hadis dari Nabi SAW. yaitu dengan mengandalkan hafalannya. ${ }^{30}$

Hadis-hadis yang dihafal jauh lebih banyak daripada hadis-hadis yang tertulis. ${ }^{31}$ Pegangan para sahabat dalam menerima hadis dari Rasulullah adalah dengan kekuatan hafalan mereka karena para sahabat yang pandai menulis sangat sedikit jumlahnya. Keotentikan hadis sangat dimungkinkan tetap terjaga karena bangsa Arab pada saat itu mempunyai kekuatan hafalan yang luar biasa, sehingga merupakan sesuatu hal yang mudah bagi mereka untuk menghafal hadis-hadis yang datang dari Rasulullah Saw. ${ }^{32}$

Pada masa Nabi, Islam telah tersebar ke sebagian Jazirah Arab. Oleh karena itu, tidak memungkinkan bagi Nabi untuk mengajarkan hadis secara langsung. Untuk itu, Nabi mengirimkan para utusannya untuk membawa surat kepada para penguasa daerah, gubernur, raja dan kaisar. Surat-surat Nabi yang dikirim tersebut dapat dimasukkan ke dalam pengajaran hadis dengan media tulisan. Surat-surat Nabi yang telah dikirim diperkirakan banyak sekali, mengingat Nabi mempunyai banyak juru tulis. Ibnu Sa'ad mencatat dalam al-Thabaqat al-Kubra surat-surat Nabi jumlahnya mencapai 105 surat. $^{33}$

Para sahabat pada umumnya sangat berminat dalam menerima hadis Nabi dan menyampaikannya kepada sahabat lain. Mereka berusaha menjaga dan mengamalkannya, sehingga ketika mereka tidak menyaksikan peristiwa yang telah berlangsung, mereka akan bertanya kepada yang lain. Perhatian mereka tersebut disebabkan beberapa hal, yaitu; 1) Mereka diperintahkan untuk mengikuti Nabi dan

\footnotetext{
${ }^{29}$ Noorhidayati, Kritik Teks..., 21-22

${ }^{30}$ Muh $\}$ ammad Abu Zahwu, al-Hadits wa al-Muhadditsun aw 'Inayah al-Ummah al-Islamiyah bi alSunnah al-Nabawiyah (Riyadh: al-Mamlakah al-'Arabiyah al-Su'udiyah, 1984), 53

${ }^{31}$ Radinal Mukhtar Harahap, "Hadis pada Masa Nabi Muhammad SAW. dan Sahabat", al-Bukhari, Vol. 1, No. 1, (Januari-Juli 2018), 45

${ }^{32}$ Zain, Sejarah Hadis..., 6

${ }^{33}$ Noorhidayati, Kritik Teks..., 24-25
} 
Sunnahnya, serta menjadikannya sebagai teladan, mereka dituntut untuk mengamalknannya dan mentaatinya, serta adanya peringatan dan ancaman dari Allah SWT bagi mereka yang mendurhakai dan mengingkari perintah-Nya; 2) Mereka diperintahkan untuk menghafal Sunnah dan menjaganya serta menyampaikannya kepada yang lain sesuai dengan apa yang mereka terima; 3) Nabi menjadikan Sunnahnya sebagai pegangan hidup dan kewajiban mengamalkannya di samping alQur'an, yang mana bagi siapa saja yang berpegang teguh dengan keduanya maka dia tidak akan pernah sesat selamanya. ${ }^{34}$

Sebagai bagian dari agama, kebenaran substantif yang tersurat dan tersirat dalam hadis Rasulullah bersumber dari Allah, atau dalam bahasa lain bersifat wahyu, bukan hasil capaian akal Rasulullah. Beliau hanya berperan sebagai media dan terlihat dalam aspek verbalisasi atau teksasi substansi kebenaran hadis tersebut. Dalam hal ini, memang berbeda dengan al-Qur'an yang kebenaran isi dan redaksional teksnya bersumber dari Allah, sedangkan hadis tidaklah demikian. Artinya, teks hadis tersebut tidak lepas dari dampak perjalanan waktu. Teks hadis dalam perjalannya dari hulu ke hilir, dari hulu pertama, Rasulullah, samapai kepada pembuku hadis, telah mmengalami imbasan sejarah dengan segenap konsekuensinya. ${ }^{35}$

Ada beberapa cara yang digunakan Rasulullh Saw.dalam menyampaikan hadis kepada para sahabaat, yaitu:

1. Melalui para jama'ah yang berada di pusat pembinaan atau majlis al- 'ilmi. Melalui majlis ini, para sahabat memperoleh banyak peluang untuk menerima hadis, sehingga mereka berusaha untuk selalu mengkonsentrasikan dirinya guna mengikuti kegiatan tersebut. Para sahabat begitu antusias untuk tetap bisa mengikuti kegiatan di majlis ini. Terkadang di antara mereka bergantian hadir, seperti yang dilakukan oleh 'Umar in al-Khaththab yang bergantian hadir dengan Ibnu Zaid dari Bani Umayyah untuk menghadiri majlis ini. ${ }^{36}$

2. Rasulullah menyampaikan hadisnya melalui para sahabat tertentu, yang kemudian oleh para sahabat tersebut disampaikannya kepada orang lain. Hal ini karena

\footnotetext{
${ }^{34}$ Ibid., 27

${ }^{35}$ Djuned, Ilmu Hadis..., 32

${ }^{36}$ Mudasir, Ilmu Hadis..., 88
} 
terkadang ketika Nabi menyampaikan suatu hadis, para sahabat yang hadir hanya beberapa orang saja, baik karena disengaja oleh Rasulullah sendiri atau secara kebetulan para sahabat yang hadir hanya beberapa orang saja.

3. Untuk hal-hal sensitif seperti yang berkaitan dengan soal keluarga dan kebutuhan biologis, terutama yang menyangkut hubungan suami istri, Nabi menyampaikan melalui istri-istrinya. ${ }^{37}$

4. Melakukan ceramah atau pidato di tempat terbuka, seperti ketika haji wada' dan fath Makkah. ${ }^{38}$

5. Melalui perbuatan Nabi langsung yang disaksikan oleh para sahabatnya, yaitu dengan jalan musyahadah, seperti yang berkaitan dengan praktik-praktik ibadah dan mu'amalah. Peristiwa-peristiwa yang terjadi pada Nabi lalu Nabi menjelaskan hukumnya dan berita itu tersebar di kalangan umat Islam. ${ }^{39}$

Sahabat yang menerima hadis dari Nabi langsung merekamnya dalam ingatan (hafalan) mereka, dan ada juga dalam bentuk tulisan atau catatan. Hadis itu kemudian disampaikan kepada sahabat lainnya, dan sahabat yang menerima hadis itu berusaha mengonfirmasikan kembali kepada Nabi. Dengan cara seperti itu, maka kemungkinan terjadinya kebohongan dan pemalsuan hadis sangat kecil. Mereka juga sangat hati-hati dan ketat dalam periwayatan hadis. Untuk mendapatkan ketenangan dan kemantapan hati mereka berusaha mendatangkan saksi ataupun meminta untuk bersumpah, terlebih bagi mereka yang diragukan kebenarannya. ${ }^{40}$

Menurut Mustafa Azami, para sahabat dalam mempelajari hadis menggunakan tiga metode, yaitu:

1. Mengunakan metode hafalan. Para sahabat biasanya mendengarkan setiap pengajaran Rasulullah yang kebanyakan diadakan di masjid, dan setelah selesai mereka biasanya menghafalkan apa yang telah disampaikan oleh Rasulullah.

2. Menggunakan metode tulisan, artinya ketika para sahabat menerima hadis Rasulullah mereka lansung menulisnya.

\footnotetext{
${ }^{37}$ Idri, Studi Hadis (Jakarta: Kencana, 2010), 34

${ }^{38}$ Mudasir, Ilmu Hadis..., 89

${ }^{39}$ Idri, Studi Hadis ..., 35

${ }^{40}$ Noorhidayati, Kritik Teks..., 28-29
} 
3. Para sahabat langsung mempraktekan apa yang telah disampaikan oleh Rasulullah. begitu pula terhadap apa yang telah mereka hafal dan mereka tulis langsung dipraktekkan, karena mereka mengetahui bahwa dalam Islam ilmu itu untuk diamalkan. ${ }^{41}$

Periwayatan pada zaman Nabi banyak berlangsung secara lisan berdasarkan hafalan masing-masing sahabat. Padahal kemampuan menghafal sahabat itu beredabeda, sehingga dalam dalam meriwayatkan hadis ada yang sesuai dengan lafal yang diterima dari Nabi (al-Riwayah bi al-lafazh). Namun, tidak sedikit pula bagi sahabat yang dalam keadaan terpaksa akan meriwayatkannya dengan maknanya (al-riwayah bi al-ma'na). ${ }^{42}$

Para sahabat tidak memiliki kadar perolehan dan penguasaan hadis yang sama antara satu dan lainnya. Hal ini bergantung pada beberapa hal, yaitu; 1) Perbedaan mereka dalam soal kesempatan bersama Rasulullah; 2) Perbedaan dalam soal kesanggupan untuk selalu bersama Rasulullah; 3)Perbedaan mereka dalam soal kekuatan hafalan dan kesunguhan bertanya kepada sahabat lain; 4)Perbedaan mereka dalam waktu masuk Islam dan jarak tempat tingal mereka dari majlis Rasulullah Saw. ${ }^{43}$

Tidak ada informasi yang terperinci mengenai jumlah para sahabat. Namun, ulama sepakat bahwa semua sahabat adalah adil (' $u d u l$ ), kecuali pendapat-pendapat aneh dari golongan yang menyimpang. Sahabat yang pertama adalah Abu Bakr alShiddiq, sedangkan sahabat yang terakhir meninggal dunia adalah Abu al-Thufail 'Amir ibn Washilah al-Laysi yang meninggal di Makkah $110 \mathrm{H}^{4}{ }^{44}$

\section{Kontroversi Larangan dan Izin Penulisan Hadis}

Sejarah mencatat bahwa, sejak masa Nabi tradisi kelisanan dan keaksaraan terhadap kajian hadis berjalan secara bersamaan. Sebagian sahabat menulis hadis dan sebagian tidak mau menulisnya. Penulisan Sunnah Nabi yang kemudian

\footnotetext{
${ }^{41}$ Zain, Sejarah Hadis..., 6

${ }^{42}$ Noorhidayati, Kritik Teks..., 28-29

${ }^{43}$ Mudasir, Ilmu Hadis..., 89-90

${ }^{44}$ Harahap, Hadis pada Masa..., 45
} 
ditransformasikan dalam bentuk hadis dilakukan dengan inisiatif sahabat sendiri, ada juga dengan perintah langsung dari Nabi. ${ }^{45}$

Pada masa permulaan Islam, Rasulullah Saw. tidak merestui para penulis wahyu mencatat sabda-sabdanya selain al-Qur'an. Sebagai tindak lanjut dari ketidaksetujun tersebut, Rasulullah Saw. memerintahkan menghapus segala catatan yang berhubungan dengan tulisan selain al-Qur'an. ${ }^{46}$ Dalam hal ini Rasulullah bersabda:

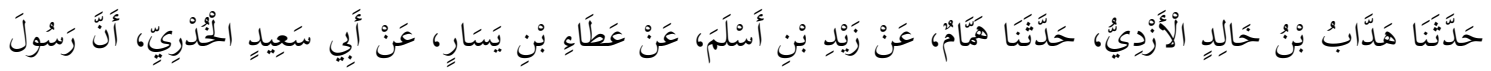

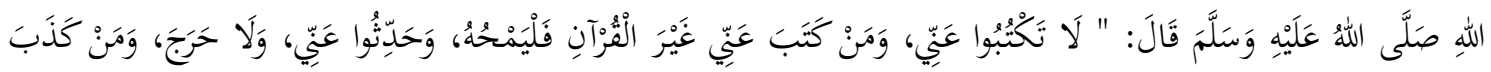

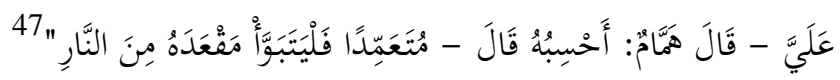

Haddab ibn Khalid al-Azdi menceritakan kepada kami, Hammam menceritakan kepada kami dari Zaid ibn Aslam, dari 'Athok ibn Yasar, dari Abu Sa id al-Khudri, bahwa Rasulullah Saw. bersabda: kalian jangan menulis apa-apa dariku. Barang siapa menulis dariku selain al-Qur'an maka hapuslah. Dan sampaikanlah hadis dariku, dan itu tidak berdosa. Barang siapa berdusta atas namaku-Hammam berkata: anggapan saya Rasulullah SAW. bersabda:- secara sengaja, maka hendaklah ia menyiapkan tempat dudukmya dari neraka.

Di samping Rasulullah Saw. menyuruh menghapus catatan selain al-Qur'an jika sudah terlanjur dicatat, beliau tidak memberi izin jika ada sahabat yang menulisnya. ${ }^{48}$

Rasulullah Saw. melarang dan tidak menyenangi para sahabat mencatat hadis yang disabdakannya. Namun, walaupun dalam riwayat-riwayat diterangkan bahwa Rasulullah Saw. melarang beberapa sahabat mencatat hadis, bukan berarti tidak memberi kesempatan kepada orang-orang tertentu untuk mencatatnya karena dalam beberapa peristiwa lain, dapat terungkap adanya kecenderungan bahwa larangan Rasulullah Saw. tidak mutlak. ${ }^{49}$

\footnotetext{
${ }^{45}$ Muhammad Anshori, “Oposisi Penulisan Hadis di Basrah pada Abad Kedua Hijriah”, Universum, Vol. 13, No. 2 (Juli 2019), 110

${ }^{46}$ M.Adurrahman dan Elan Sumarna, Metode Kritik Hadis (Bandung: Remaja Rosdakarya, 2011), 2

${ }^{47}$ Imam Abi al-Husayn Muslim bin al-Hajjaj al-Qusyairi al-Naisaburi, Sahih Muslim (Riyad, Dar Bayt alAfkar, 1998), 1201

${ }^{48}$ Adurrahman, Metode Kritik..., 2

${ }^{49}$ Ibid.., 3
} 
1. Adanya larangan tersebut berakibat banyak hadis yang tidak ditulis dan seandainya Nabi tidak pernah melarang, tidak mungkin hadis dapat ditulis. Hal ini disebabkan oleh beberapa faktor, sebagaimana dijelaskan oleh M. Syuhudi Ismail, yaitu; Hadis disampaikan tidak selalu dihadapan sahabat yang pandai menulis hadis.

2. Perhatian Nabi dan para sahabat lebih banyak tercurah pada al-Qur'an.

3. Meskipun Nabi mempunyai beberapa sekretaris tetapi mereka hanya diberi tugas menulis wahyu yang turun dan surat-surat Nabi.

4. Sangat sulit seluruh pernyataan, perbuatan, taqrir, dan hal ihwal orang yang masih hidup dapat langsung dicatat oleh orang lain apalagi dengan peralatan yang sangat sederhana. $^{50}$

Kitabullah menyita sebagian besar waktu dan menguasai seluruh perasaan sahabat. Sedangkan hadis Rasulullah pada waktu itu terlalu banyak untuk dapat dihitung. Setiap peristiwa diikuti sabda Nabi, setiap permintaan fatwa ada penjelasan dari beliau, dan dalam banyak wahyu al-Qur'an terdapat keterangan serta penafsiran dari Rasulullah. Jadi, bagaimana mungkin para penulis mengikuti Rasulullah Saw. ke manapun beliau pergi dan menuliskan semua perkataan, perbuatan dan ketetapannya. ${ }^{51}$

Para sahabat berusaha menghafal hadis yang diterima dari Rasulullah Saw. dengan sungguh-sungguh. Mereka sangat takut dengan ancaman Rasulullah Saw. sehingga berusaha agar tidak melakukan kekeliruan terhadap apa yang diterimanya.

Ada dorongan kuat yang cukup memberikan motivasi kepada para sahabat dalam kegiatan menghafal hadis, yaitu; 1) Kegiatan menghafal merupakan budaya bangsa Arab yang telah diwarisi sejak masa pra-Islam dan mereka terkenal kuat hafalannya; 2) Rasulullah SAW. banyak memberikan spririt melalui doa-doanya; 3) Seringkali beliau menjanjikan kebaikan akhirat bagi mereka yang menghafal hadis dan menyampaikannya kepada orang lain ${ }^{52}$

Para sahabat mampu menghafal hadis di luar kepala dan meriwayatkannya secara musyafahah. Hanya sedikit dari golongan sahabat yang menulis hadis seperti

\footnotetext{
${ }^{50}$ Idri, Studi Hadis..., 37

${ }^{51}$ al-Shalih, Membahas Ilmu-ilmu..., 35

${ }^{52}$ Mudasir, Ilmu Hadis..., 86
} 
'Abdullah ibn 'Amr ibn al-'Ash yang diberikan ijin oleh Rasulullah Saw. untuk menulis hadis, ${ }^{53}$ seperti yang tertulis di dalam hadis berikut ini:

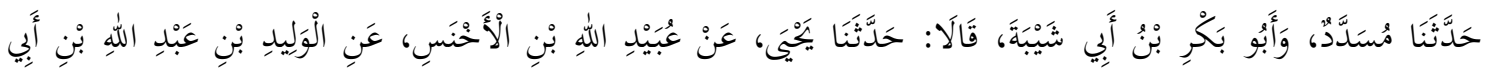

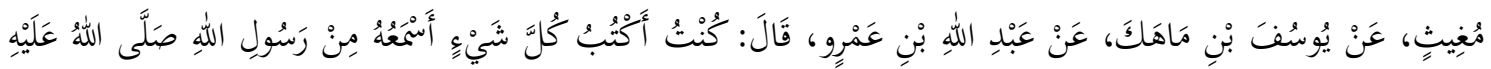

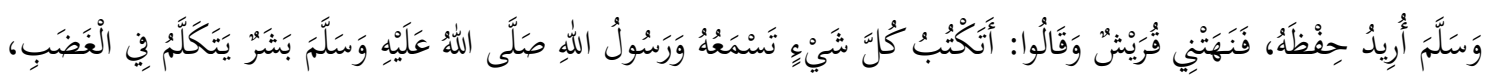

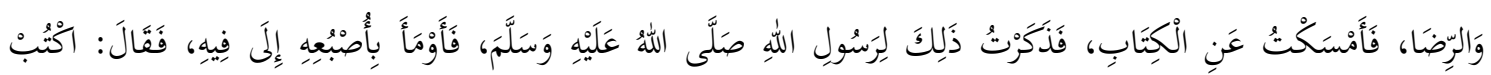

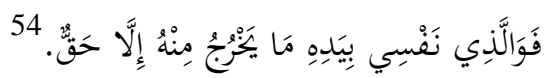

Musaddad dan Abu Bakr ibn Abi Syaibah menceritakan kepada kami, dari 'Ubayd Allah ibn al-Akhnas, dari al-Walid ibn 'Abd Allah ibn Abi Mughits, dari Yusuf ibn Mahak, dari 'Abd Allah ibn 'Amr. Ia berkata: saya menulis setiap hadis yang saya dengar dari Rasulullah Saw. saya ingin menghafalkannya, kemudian orang Quraisy melarang saya. Mereka berkata: apakah kamu menulis setiap apa yang kamu dengar dari Rasulullah SAW., dan beliau adalah manusia yang berbicara dalam keadaan marah atau senang. Maka saya berhenti menulis hadis. Kemudian saya menceritakan hal tersebut pada Rasulullah Saw., kemudian beliau menunjuk dengan jarinya ke mulutnya. Kemudian beliau bersabda: Tulislah! Demi jiwaku yang ada di tangan-Nya, tidak keluar darinya (mulut Rasulullah Saw) kecuali yang hak.

Hadis tentang izin penulisan hadis yang diriwayatkan oleh'Abdullah ibn 'Amr tersebut memang tampak bertentangan dengan hadis yang diriwayatkan oleh Abu Sa'id al-Khudri yang mengandung larangan penulisan hadis. Untuk menghadapi dua hadis tersebut terdapat beberapa pendapat, yaitu:

1. Larangan menulis hadis terjadi pada periode permulaan, sedangkan izin penulisannya diberikan pada periode akhir kerasulan.

2. Larangan penulisan hadis itu ditujukan bagi orang yang kuat hafalannya dan tidak dapat menulis dengan baik, serta dikhawatirkan salah dan bercampur dengan alQur'an. Izin menulis hadis diberikan kepada orang yang pandai menulis dan tidak dikhawatirkan salah serta bercampur dengan al-Qur'an.

\footnotetext{
${ }^{53}$ Abu Zahwu, al-Hadits wa al-Muhadditsun..., 54

${ }^{54}$ Abu Dawud Sulaiman ibn al-Asy'ats al-Sijistani, Sunan Abu Dawud (Riyadh: Bayt al-Afkar alDawliyyah, t.th.), 403
} 
3. Larangan itu ditujukan bagi orang yang kurang pandai menulis dikhawatirkan tulisannya keliru, sementara orang yang pandai menulis tidak dilarang menulis hadis.

4. Larangan menulis hadis dicabut (di-mansukh) oleh izin menulis hadis, karena tidak dikhawatirkan tercampurnya catatan hadis dengan al-Qur'an.

5. Larangan itu bersifat umum, sedangkan izin menulis hadis bersifat khusus kepada para sahabat yang dijamin tidak akan mencampurkan catatan hadis dan catatan alQur'an.

6. Larangan ditujukan untuk kodifikasi formal, sedangkan izin ditujukan untuk sekadar dalam bentuk catatan yang dipakai sendiri.

7. Larangan berlaku ketika wahyu masih turun, belum dihafal dan dicatat. Adapun ketika wahyu yang turun sudah dihafal dan dicatat, maka penulisan hadis diizinkan. $^{55}$

Dari dua versi hadis tersebut dapat diambil kesimpulan bahwa tidak mungkin munculnya kedua versi tersebut dalam satu waktu dan serentak. Dalam hal ini, bahwa kemungkinan munculnya pelarangan pencatatan hadis lebih dahulu ada dari pada pembolehan pencatatan hadis. Diperbolehkannya pencatatan hadis itu sendiri setelah hilangnya sebab-sebab yang berimplikasi pada pelarangan. Para sahabat pada mulanya selalu bersegera mencatat apa saja yang terjadi dan yang diajarkan oleh Rasulullah, dan hal itu diperbolehkannya. ${ }^{56}$ Terlepas dari adanya hadis-hadis yang bertentangan dalam masalah penulisan hadis, ternyata di antara para sahabat terdapat mereka yang memiliki kumpulan-kumpulan hadis dalam bentuk tertulis secara pribadi. ${ }^{57}$

Para peneliti menerangkan bahwa, hadis yang pernah dicatat oleh para sahabat pada zaman Rasulullah Saw. ada dua bentuk, yaitu yang disebut al-shahifah dan almajmu'ah. al-Shahifah al-Shadiqah ialah pencatatn hadis yang dilakukan oleh 'Adullah in 'Amr, sedangkan al-Shahifah al-Shahihah ditulis oleh Hammam ibn Munabbih. Sementara itu, al-Majmu'ah merupakan hadis yang dikumpulkan oleh Ali in Abi Thalib,

\footnotetext{
${ }^{55}$ Idri, Studi Hadis..., 37-38

${ }^{56}$ Munawir Umar, "Otentisitas dan Validitas Hadis Nabi serta Contoh-contoh Haditsnya dan Problematikanya”, Journal of Qur'an and Hadits Studies, Vol. 6, No.1 (Januari-Juni 2017), 6

${ }^{57}$ Abduh, Melacak Akar..., 68
} 
Ibnu Abbas, dan Ibnu Mas‘ud. Jadi, jelaslah pada zaman Rasulullah Saw. sudah ada catatan hadis pada sahabat-sahabat tertentu. ${ }^{58}$

Golongan yang melarang penulisan hadis adalah; 'Umar, Ibnu Mas'ud, Zaid ibn Tsabit, Abu Musa, Abu Sa'id al-Khudri, dan sekelompok lainnya dari sahabat. Sedangkan kelompok yang membolehkan dan melakukan penulisan hadis adalah; 'Ali ibn Abi Thalib, Hasan ibn 'Ali, Anas ibn Malik, 'Abdullah ibn 'Amar, dan sekelompok lainnya dari sahabat r.a. ${ }^{59}$

Larangan pencatatan hadis pada zaman Rasulullah Saw. tampaknya tergantung pada pribadi pencatat, kebutuhan, kemampuan dan sejauh mana mereka dapat membedakan antara al-Qur'an dan hadis, sehingga tidak tercampur antara keduanya. Di samping itu, ada juga ulama yang berpedapat bahwa keterangan yang melarang pencatatan hadis sudah di-mansukh oleh keterangan yang membolehkannya. ${ }^{60}$ Hadishadis tentang pelarangan menulis hadis di-nasakh oleh hadis-hadis yang membolehkan pencatatan hadis. Dalam artian bahwa, pelarangan kodifikasi hadis sebenarnya hanya pada masa permulaan Islam, karena ditakutkan bercampurnya antara hadis dan alQur'an. Tetapi, ketika kuantitas kaum muslimin sudah mulai signifikan dan mereka sudah banyak yang mendalami isi kandungan al-Qur'an serta dapat membedakan antara kandungan hadis dan al-Qur'an, maka di-nasakh-lah hukum pelarangan tersebut menjadi boleh. ${ }^{61}$

Pada masa Nabi dan sahabat, larangan penulisan hadis masih dianggap hal yang wajar. Hal ini disebabkan karena mereka lebih memfokuskan untuk mengkaji alQur'an, karena proses pewahyuan masih berlangsung pada masa Nabi. Lebih-lebih pada masa Abu Bakr (w. $13 \mathrm{H}$ ), pengumpulan mushhaf al-Qur'an mulai dilakukan. Sedangkan pada masa 'Utsman (w. $35 \mathrm{H}$ ), telah terjadi penyeragaman mushhaf alQur'an supaya umat Islam tidak terpecah belah. Meskipun demikian, beberapa sahabat memang tetap menulis hadis karena merasa ada kebutuhan. ${ }^{62}$

\footnotetext{
${ }^{58}$ Adurrahman, Metode Kritik Hadis..., 7

${ }^{59}$ al-Qaththan, Pengantar Studi..., 48

${ }^{60}$ Adurrahman, Metode Kritik Hadis..., 7

${ }^{61}$ Umar, Otentisitas dan Validitas..., 5-6

${ }^{62}$ Anshori, Oposisi Penulisan..., 111
} 


\section{E. Catatan-catatan Hadis di Kalangan Sahabat}

Beberapa riwayat tentang penulisan hadis pada masa kenabian tampak kontradiktif. Ada riwayat yang berasal dari Rasulullah Saw. yang membolehkan untuk menulis hadis, dan terjadi kegiatan penulisan hadis pada masa Rasulullah. Adapula sahabat yang meriwayatkan hadis yang mengindikasikan larangan penulisan hadis. Para sarjana muslim protektor yang didasari oleh tendensi menyelamatkan keotentikan penulisan al-Qur'an cenderung berpendapat bahwa, pada umumnya sahabat menahan diri dari melakukan penulisan hadis pada masa kenabian dan pada masa pemerintahan Khulafa' al-Rasyidin. Hal tersebut karena besarnya keinginan mereka untuk menyelamatkan al-Qur'an dan Sunnah. Akan tetapi keadaaan demikian tidak berlangsung lama, karena 'illat larangan untuk menuliskan hadis secara bertahap hilang, maka semakin banyak pula para sahabat yang membolehkan penulisan hadis. ${ }^{63}$

Terdapat dua pendapat mengenai adanya penulisan Hadis pada masa Nabi Saw., yaitu; Pertama, pendapat yang secara tegas mengatakan bahwa hadis telah dicatat oleh para sahabat ketika Nabi Muhammad masih hidup. Pendapat ini diikuti oleh mayoritas pemikir muslim, di antaranya Mustafa Azami; Kedua, pendapat yang menolak bahwa hadis atau perkataan dan tingkah laku Nabi telah dicatat sejak Nabi masih hidup. Pendapat ini disetujui oleh sebagian besar pemikir Barat modern, termasuk juga beberapa pemikir Muslim modern. Beberapa tokoh barat yang terkenal dengan pendapat ini, diantaranya Goldziher, Schacht, Juynboll dan lain-lain. ${ }^{64}$

Menurut Azami, sahabat telah melakukan pencatatan atas riwayat atau lika-liku kehidupan Nabi. Ini bisa dibuktikan lewat beberapa karya sahabat pada masa awal. ${ }^{65}$ Banyak para sahabat yang memiliki catatan dan melakukan penulisan hadis, baik untuk disimpan sebagai catatan pribadi maupun untuk memberi pesan kepada orang lain dalam bentuk surat dengan membubuhkan hadis. ${ }^{66}$ Sahabat-sahabat yang memiliki tulisan hadis di antaranya:

\footnotetext{
${ }^{63}$ Abduh, Melacak Akar..., 68

${ }^{64}$ Yusran, "Kodifikasi Hadis Sejak Masa Awal Islam hingga Terbitnya Kitab al-Muwaththa", Tahdis, Vol. 8, No. 2 (2017), 177

${ }^{65}$ Ibid., 177

${ }^{66}$ Sahrani, Ulumul Hadits..., 55
} 
1. 'Abdullah ibn 'Amr (27 SH-63 H). Ia memiliki catatan hadis yang menurut pengakuannya dibenarkan oleh Rasulullah Saw., sehingga dinamakan al-Shahifah al-Shadiqah. ${ }^{67}$ Hadis-hadis yang terhimpun dalam catatan 'Abdullah ibn 'Amr sekitar seribu hadis. ${ }^{68}$ Shahifah ini dapat kita temukan dalam Musnad Imam Ahmad dengan sanad dari 'Abdullah ibn 'Amr. ${ }^{69}$

2. Jabir ibn 'Abdullah ibn 'Amr al-Anshari (16 SH-78H). Ia memiliki catatan hadis dari Rasulullah Saw. tentang manasik haji. Hadis tersebut kemudian diriwayatkan oleh Muslim. Catatannya ini dikenal dengan Shahifah Jabir. Banyak ulama yang menyimpan tulisan-tulisan hadis darinya, di antaranya Amir al-Sya'bi, Qatadah, dan Mujahid. ${ }^{70}$

3. Anas ibn Malik (10 SH-93H), di samping ia sendiri menulis dan menghafal hadis, ia juga mendorong putra-putranya untuk menulis hadis. Anas memiliki catatan hadis untuk kepentingan pribadi dan untuk mengajarkan kepada orang lain. Ia juga menulis hadis untuk orang lain, seperti Anas ibn Sirin. Ada juga murid-muridnya yang menulis hadis yang diterima darinya seperti Tsumamah ibn 'Ubaidillah dan Katsir ibn Salim. ${ }^{71}$

4. Abu Bakr al-Shiddiq (50 SH-13 H). Diceritakan oleh Aisyah r.a. bahwa Abu Bakr mengumpulkan hadis dari Rasulullah sebanyak 500 hadis. ${ }^{72}$ Namun, al-Dzahabi berpendapat bahwa riwayat tersebut tidak shahih. ${ }^{73}$ Sedangkan hadis-hadis yang ditulis oleh Abu Bakar di antaranya yaitu; a) Surat kepada Anas ibn Malik, gubernur Bahrain. Abu Bakar mencantumkan beberapa hadis tentang wajibnya membayar zakat bagi orang Islam; b) Surat kepada 'Amr ibn al-'Ash, di mana dalam surat itu dicantumkan beberapa hadis. ${ }^{74}$

\footnotetext{
${ }^{67}$ Mudasir, Ilmu Hadis..., 92

${ }^{68}$ Sahrani, Ulumul Hadits..., 55

${ }^{69}$ al-Qaththan, Pengantar Studi..., 50

${ }^{70}$ Sahrani, Ulumul Hadits..., 56

${ }^{71}$ Ibid.

${ }^{72}$ Ibid.

${ }^{73}$ Azami, Hadis Nabawi..., 133

${ }^{74}$ Ibid., 135
} 
5. Abu Hurairah (19 SH-59 H). Rasulullah Saw. pernah mendoakannya agar selalu hafal hadis-hadis yang diterima dari beliau. Pada awalnya, Abu Hurairah tampaknya tidak mempunyai catatan-catatan hadis $^{75}$, sebab beliau berkata:

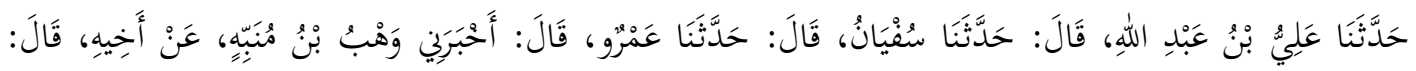

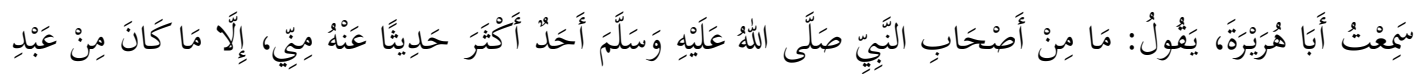

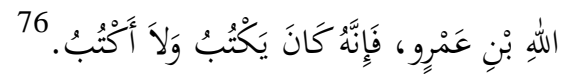

'Ali ibn 'Abdillah menceritakan kepada kami, ia berkata: Sufyan menceritakan kepada kami, ia berkata: 'Amr menceritakan kepada kami, ia berkata: Wahb ibn Munabbih menceritakan kepada kami dari saudaranya, ia berkata: tidak ada seorangpun dari sahabat-sahabat Nabi Saw. yang lebih banyak hadisnya dariku kecuali 'Abdullah ibn 'Amr, karena ia menulis sedangkan saya tidak menulis.

Keterangan Abu Hurairah tersebut bukan hanya sekedar memberikan bukti terbatasnya para sahabat yang menghimpun hadis melalui tulisan, tetapi juga merupakan suatu pertanda bahwa di kalangan para sahabat ada yang mencatat hadis dan ada pula yang tidak mencatatntya karena mereka mencukupkan dengan hafalan. ${ }^{77}$ Salah satu Shahifah ada yang diriwayatkan dari Abu Hurairah oleh muridnya Hammam ibn Munabbih, lalu shahifah tersebut dinisbatkan kepadanya sehingga orang menyebutnya Shahifah Hammam. Namun, pada kenyataannya ia merupakan Shahifah Abu Hurairah. ${ }^{78}$ Keberadaan Shahifah ini secara utuh ada pada Musnad Amad, sedangkan dalam kitab Shahih Bukhari dan lainnya terpisah dalam beberapa bab. ${ }^{79}$ Shahifah ini juga sudah dicetak dan diedit oleh DR. Muhammad Hamidullah. ${ }^{80}$

6. Abu Syah (Umar ibn Sa'ad al-Anmari) adalah seorang penduduk Yaman. Ia meminta kepada Rasulullah Saw. dicatatat hadis yang disampaikannya ketika beliau

\footnotetext{
${ }^{75}$ Ibid., 137

${ }^{76} \mathrm{Abu}$ 'Abd Allah Muh\{ammad ibn Isma'il al-Bukhari, Sahih al-Bukhari (Riyadh: Bayt al-Afkar alDawliyyah, 1998), 47

${ }^{77}$ Adurrahman, Metode Kritik Hadis..., 9

${ }^{78}$ al-Qaththan, Pengantar Studi..., 50

${ }^{79}$ Ibid.

${ }^{80}$ Azami, Hadis Nabawi..., 142
} 
berpidato pada peristiwa futuh Makkah sehubungan dengan terjadinya pembunuhan yang dilakukan oleh sahabat dari Bani Khuza'ah terhadap salah seorang lelaki Bani Lais. $^{81}$

7. 'Ali ibn Abi Thalib (23 SH-40 H), selain sebagai salah seorang penulis pribadi Rasulullah Saw., ia juga memiliki catatan pribadi yang berisi beberapa hadis. ${ }^{82}$

Pada umumnya, sahabat-sahabat yang menulis hadis bukan untuk disebarkan secara luas, tetapi lebih sebagai koleksi pribadi. Seiring dengan berjalannya waktu, hadis-hadis yang mereka tulis kemudian diriwayatkan oleh murid-murid mereka. ${ }^{83}$

Dalam hal ini, pembukuan (kodifikasi) berbeda dengan penulisan. Seseorang yang menulis sebuah shahifah maka dipahami sebagai penulisan (hadis). Sedangkan pembukuan adalah mengumpulkan shahifah yang sudah tetulis dan yang dihafal, lalu menyusunnya sehingga menjadi satu buku. ${ }^{84}$ Sedangkan kodifikasi hadis atau tadwin hadis pada periode kodifikasi adalah kodifikasi secara resmi berdasarkan perintah kepala negara yaitu pada pemerintahan 'Umar ibn Abdul Aziz. ${ }^{85}$

Pada masa sahabat besar, perhatian sahabat juga masih terfokus pada pemeliharaan dan penyebaran al-Qur'an. Dengan demikian, periwayatan hadis belum begitu berkembang, bahkan mereka berusaha membatasi periwayatan hadis. Oleh karena itu, masa ini oleh para ulama dianggap sebagai masa yang menunjukkan adanya pembatasan atau memperketat periwayatan (al-tatsabut wa al-iqlal al-riwayah). ${ }^{86}$

Menurut al-Dzahabi, Abu Bakr r.a. adalah orang pertama yang memperketat periwayatan hadis. ${ }^{87}$ Sikap kehati-hatian juga ditunjukkan oleh 'Umar ibn al-Khaththab. Seperti halnya Abu Bakar, 'Umar juga meminta diajukan saksi jika ada orang yang

\footnotetext{
${ }^{81}$ Sahrani, Ulumul Hadits..., 56

${ }^{82}$ Ibid.

${ }^{83}$ Anshori, Oposisi Penulisan..., 111-112

${ }^{84}$ al-Qaththan, Pengantar Studi..., 50

${ }^{85}$ Abduh, Melacak Akar..., 71

${ }^{86}$ Sahrani, Ulumul Hadits..., 57

${ }^{87}$ Muhammad 'ajaj al-Khatib, Ushul al-Hadits 'Ulumuh wa Musthalahuh (t.t: Dar al-Fikr,1971), 89
} 
meriwayatkan hadis. ${ }^{88}$ Sedangkan 'Ali ibn Abu Thalib justru menerapkan sumpah terhadap sahabat yang meriwayatkan hadis kepadanya. ${ }^{89}$

Terhadap hadis harus ada pembuktian apakah ia benar-benar berasal dari Rasulullah. Sebab, meskipun hadis itu disandarkan kepada Rasulullah, tetapi tidak semuanya benar-benar otentik dari beliau. Pada saat hadis belum didokumentasi dalam kitab-kitab, pernah terjadi pemalsuan hadis untuk kepentingan politik dan kepentingan lainnya, yang dikenal dengan peredaran hadis mawdhu ‘90

Dalam pembahasan ayat al-Qur'an tidak ditemukan pertanyaan "mushhaf yang mana?", karena di kalangan Syi'ah atau Sunni mushhaf itu hanya satu versi yaitu mushaf 'Utsmani seperti yang dibaca orang Islam. Sementara itu, hadis ada sekian versi karena ditulis oleh individu-individu dengan kecenderungan yang berbeda-beda. ${ }^{91}$

Ketika Rasulullah wafat, naskah al-Qur'an sudah siap didokumentasi kendati sebagian berada di tangan seorang sahabat tertentu, dan sebagian yang lain berada di tangan sahabat yang berbeda. Tidak ada ayat al-Qur'an yang terluput dari rekaman tertulis. Susunan dan sistematika (tartib) surah dan ayat-ayat al-Qur'an dalam mushhaf al-Qur'an diyakini umat Islam berdasarkan petunjuk Rasulullah (atas petunjuk Allah). ${ }^{92}$ Sedangkan hadis tidak terfikirkan untuk didokumentasi seperti al-Qur'an. ${ }^{93}$

Pada masa ini belum ada usaha secara resmi untuk menghimpun hadis dalam satu kitab, seperti halnya al-Qur'an. Hal ini disebabkan antara lain; 1) Agar tidak memalingkan umat Islam dalam mempelajari al-Qur'an; 2) Para sahabat yang banyak menerima hadis Rasulullah Saw. sudah tersebar ke berbagai daerah kekuasaan masingmasing sebagai pembina masyarakat, sehingga dengan kondisi seperti ini ada kesulitan mengumpulkan mereka secara lengkap; 3) Pembukuan hadis di kalangan para sahabat

\footnotetext{
${ }^{88}$ Sahrani, Ulumul Hadits..., 59

${ }^{89}$ al-Khathib, Ushul al-Hadits, 90

${ }^{90}$ Zuhri, Telaah Matan..., 2

${ }^{91}$ Ibid., 3

${ }^{92}$ Ibid., 5

${ }^{93}$ Ibid.
} 
sendiri terjadi perselisihan pendapat, belum lagi terjadinya perselisian soal lafal dan keshahih-annya. ${ }^{94}$

Inisiatif untuk mendokumentasikan hadis pernah muncul pada masa kekhalifahan 'Umar ibn al-Khaththab, tetapi inisiatif tersebut akhirnya diurungkan. Tidak direalisasikannya niat itu bukan karena takut hadis tercampur dengan al-Qur'an, tetapi karena hawatir umat Islam terlalu terkonsentrasi untuk belajar hadis dan mengabaikan al-Qur'an. ${ }^{95}$

Terdapat riwayat dari Urwah ibn al-Zubair bahwa 'Umar ibn al-Khaththab ingin menulis Sunnah-sunnah Nabi, lalu beliau meminta fatwa dari para sahabat tentang hal itu, dan mereka menyarankan untuk menulisnya. Kemudian 'Umar beristikharah selama satu bulan, hingga pada suatu pagi beliau akhirnya mendapatkan kemantapan hati, lalu berkata, "Suatu ketika aku ingin menulis Sunnah-sunnah, dan aku ingat suatu kaum terdahulu, mereka menulis buku dan meningalkan Kitabullah. Demi Allah, aku tidak akan mengotori Kitabullah dengan suatu apapun.

Ini menunjukkan bahwa, 'Umar ingin menulis al-Sunnah dan membukukannya, namun khawatir kaum muslimin akan terlena mempelajarinya dan melalaikan Kitabullah, atau khawatir akan tercampur antara al-Sunnah dengan Kitabullah. Seandainya 'Umar tidak melihat pentingnya pembukuan hadis dan pengumpulannya, tentulah tidak menginginkan hal itu. Ia hanya menahan diri dari larangan yang telah dibuatnya. ${ }^{96}$

Berdasarkan riwayat tersebut, kita bisa mengetahui bahwa,'Umar ibn alKhaththab juga pernah berinisiatif melakukan penulisan hadis sebelum adanya kodifikasi hadis secara resmi pada masa pemerintahan 'Umar ibn Abdul Aziz. Namun, keinginan tersebut diurungkan oleh 'Umar ibn al-Khaththab karena khawatir kaum muslimin akan meninggalkan al-Qur'an. Adanya penulisan hadis di masa Rasulullah juga tidak bisa dipungkiri, hal tersebut dapat kita lihat dari catatan-catatan hadis yang ditulis oleh sebagian sahabat dan periwayatannya bisa kita baca hingga sekarang.

\footnotetext{
${ }^{94}$ Sahrani, Ulumul Hadits..., 59

${ }^{95}$ Zuhri, Telaah Matan..., 6

${ }^{96}$ al-Qaththan, Pengantar Studi..., 51
} 


\section{F. Kesimpulan}

Bangsa Arab dikenal sebagai bangsa yang ummi (tidak bisa membaca dan menulis), bahkan ketika Islam datang hanya terdapat 17 orang yang bisa menulis di kalangan suku Quraisy. Pada masa Nabi Saw. tulis-menulis sudah berkembang cukup luas. Rasulullah mengangkat para penulis wahyu yang jumlahnya mencapai 40 orang. Pada masa itu juga sudah ada penulis wanita, di antaranya yaitu Ummul Mu'minin Hafshah.

Para penulis lebih banyak di Makkah daripada di Madinah, Namun, setelah perang Badar Para penulis semakin banyak di Madinah. Rasulullah mengizinkan tawanan dari Makkah dalam perang Badar untuk mengajarkan menulis dan membaca kepada 10 anak Madinah sebagai tebusan diri mereka.

Pada masa Nabi, para penulis telah berkembang pesat, dimana al-Qur'an dapat dirangkum dengan sekumpulan naskah-naskah yang ada pada sahabat-sahabat yang menulis wahyu al-Qur'an. Sedangkan Hadis-hadis lebih banyak yang dihafal daripada yang tertulis, sehingga dalam meriwayatkan hadis ada yang menggunakan al-Riwayah bi al-lafazh dan ada juga yang menggunakan al-riwayah bi al-ma'na.

Pada masa permulaan Islam, Rasulullah Saw. tidak merestui para penulis wahyu mencatat sabda-sabdanya selain al-Qur'an. Rasulullah Saw. memerintahkan sahabat menghapus catatan selain al-Qur'an jika sudah terlanjur dicatat. Namun, pada keadaan tertentu ada juga sahabat yang diberi izin untuk menulis hadis seperti 'Abdullah ibn 'Amr. Larangan pencatatan hadis pada zaman Rasulullah Saw. tergantung pada pribadi dan kemampuan sahabat dalam membedakan antara al-Qur'an dan hadis supaya tidak tercampur antara keduanya. Di samping itu, ada juga ulama yang berpedapat bahwa larangan penulisan hadis sudah di-mansukh.

Hadis yang pernah dicatat oleh para sahabat pada zaman Rasulullah Saw. ada dua bentuk, yaitu yang disebut al-shahifah dan al-majmu'ah. Sahabat-sahabat yang memiliki tulisan hadis di antaranya; 'Abdullah ibn 'Amr, Jabir ibn 'Abdullah ibn 'Amr al-Anshari, Anas ibn Malik, Abu Bakr al-Shiddiq, Abu Hurairah, Abu Syah (Umar ibn Sa'ad al-Anmari) dan 'Ali ibn Abi Thalib. 


\section{Daftar Pustaka}

Abduh, Muhammad. Melacak Akar Kesejarahan Hadis Nabi Pra-Kodifikasi. Tahdis, Vol. 6, No. 1. 2015.

Abdurrahman, $\mathrm{M}$ dan Elan Sumarna. Metode Kritik Hadis. Bandung: Remaja Rosdakarya, 2011.

Abu Zahwu, Muhammad. al-Hadits wa al-Muhadditsun aw 'Inayah al-Ummah alIslamiyah bi al-Sunnah al-Nabawiyah. Riyad: al-Mamlakah al-'Arabiyah alSu'udiyah, 1984.

Anshori, Muammad. Oposisi Penulisan Hadis di Basrah pada Abad Kedua Hijriah. Universum. Vol. 13, No. 2. Juli 2019.

Azami, M.M. Hadis Nabawi dan Sejara Kodifikasinya, terj. Ali Mustafa Yaqub. Jakarta: Pustaka Firdaus, 1994.

Baidan, Nashruddin. Wawasan Baru Ilmu Tafsir. Yoyakarta: Pustaka Pelajar, 2011.

Bukhari (al), Abu 'Abd Allah Muhammad ibn Isma'il. Sahih al-Bukhari. Riyadh: Bayt al-Afkar al-Dawliyyah, 1998.

Djuned, Daniel. Ilmu Hadis. t.t.: Erlangga, 2010.

Harahap, Radinal Mukhtar. Hadis pada Masa Nabi Muhammad SAW. dan Sahabat. alBukhari. Vol. 1, No. 1. Januari-Juli 2018.

Idri. Hadis dan Orientalis: Perspektif Ulama Hadis dan Para Orientalis tentang Hadis Nabi. Jakarta: Kencana, 2017.

_. Studi Hadis. Jakarta: Kencana, 2010.

Khatib (al), Muhammad 'ajaj. Ushul al-Hadits 'Ulumuh wa Musthalahuh.t.t: Dar alFikr, 1971.

Mudasir. Ilmu Hadis. Bandung: Pustaka Setia, 1999.

Noorhidayati, Salamah. Kritik Teks Hadis. Yogyakarta: Dialektika, 2017.

Qaththan (al), Manna'. Pengantar Studi Ilmu Hadits, terj. Mifdhol Abdurrahman. Jakarta: al-Kautsar, 2005.

Sahrani, Sohari. Ulumul Hadits. Bogor: Ghalia Indonesia, 2010.

Shalih (al), Subhi. Membahas Ilmu-ilmu Hadis, terj. Tim Pustaka Firdaus. jakarta: Pustaka Firdaus, 2009. 
Umar, Munawir. Otentisitas dan Validitas Hadis Nabi serta Contoh-contoh Haditsnya dan Problematikanya. Journal of Qur'an and Hadits Studies. Vol. 6, No.1. Januari-Juni 2017.

Yusran. Kodifikasi Hadis Sejak Masa Awal Islam hingga Terbitnya Kitab alMuwaththa. Tahdis. Vol. 8, No. 2. 2017.

Zain, Lukman. Sejarah Hadis pada Masa Permulaan dan Penghimpunannya. Diya alAfkar. Vol. 2, No. 1. Juni 2014.

Zuhri, Muh. Telaah Matan Hadis Sebuah Tawaran Metodologis. Yoyakarta: LESFI, 2003. 